\title{
Research
}

\section{Biophysical, Socioeconomic, and Geopolitical Vulnerabilities to Hydropower Development on the Nu River, China}

\author{
$\underline{\text { Desiree D. Tullos }}^{1}, \underline{\text { Eric Foster-Moore }}^{2}, \underline{\text { Darrin Magee }}^{3}, \underline{\text { Bryan Tilt }}^{1}, \underline{\text { Aaron T. Wolf }}^{1}, \underline{\text { Edwin Schmitt }}^{4}, \underline{\text { Francis Gassert }}^{5}$ \\ and $\underline{\text { Kelly Kibler }}^{1}$
}

\begin{abstract}
Rapid hydropower development is occurring in China's Yunnan province in response to increasing clean energy demands, exposing potential vulnerabilities of the area's ecosystems, communities, and geopolitical systems. Here, we present original data on the cultures, economics, hydro-politics, and environments of the Nu River basin, based on household surveys, analysis of geopolitical events, and hydrological, hydraulic, and landscape modeling. We identify sources of vulnerability and investigate relationships among biophysical, socioeconomic, and geopolitical elements that contribute to vulnerability. Our results illustrate the role of geographic isolation in intensifying vulnerability to hydropower development and how access to information, data uncertainty, and geopolitics influence the vulnerability of people and the environment. We emphasize specific needs for developing support mechanisms for social, ecological, and political groups that are vulnerable to hydropower development.
\end{abstract}

Key Words: China; dams; hydroelectric power; hydro-politics; international rivers; Nu River; resettlement; Salween River; vulnerability; Yunnan Province

\section{INTRODUCTION}

Hydropower development in China is occurring at unprecedented scales. The increasing demand for electricity in China, along with the Chinese central government's push for reducing carbon emissions, is driving an aggressive hydropower development scenario that envisions up to 270 GW of installed hydroelectric capacity by 2015 and as much as 330 GW by 2020 (China Electricity Council: http://www. cec.org.cn/hangyeguangjiao/fadianxinxi/2010-11-27/19583.html). China's 12th Five-Year Plan (2011-2015), released in March 2011, calls for accelerated construction of large-scale hydropower in southwest China (China Economic Net: http:// en.ce.cn/subject/17cpc/17cpc12/201103/05/t20110305 22271354. shtml).

Southwest China, and Yunnan Province in particular, is a major focus for large-scale hydropower development because of the steep terrain and high-volume rivers. The Three Parallel Rivers, i.e., the $\mathrm{Nu}$ (known as the Salween outside of China), Lancang (Mekong), and Jinsha (upper Yangtze) rivers, are especially attractive because the combined theoretically exploitable hydropower potential on these three rivers alone exceeds $100 \mathrm{GW}$; of this, $60 \mathrm{GW}$ was already under development as of September 2011 (Magee 2012). Moreover, hydropower development in southwest China is situated within a policy context that prioritizes investments in infrastructure in China's west as part of the Western Development Campaign (2001-present) and a host of other policies that justify and lend urgency to the extraction of western resources for the benefit of eastern development (Goodman 2004, Naughton 2004, Magee 2006).
While the potential for power generation from China's Three Parallel Rivers is large, so too is the potential for adverse social and environmental effects. Globally, the impacts of hydropower development are well documented (Goldsmith and Hildyard 1986, World Commission on Dams 2000, Padovani 2004, Nilsson et al. 2005, Scudder 2005). The Three Parallel Rivers area is especially vulnerable to hydropower development partly because of the rich cultural and biological diversity of the area (UNESCO World Heritage Convention 2003, Yang et al. 2004). Furthermore, two of these rivers, the $\mathrm{Nu}$ and Lancang, are transboundary rivers that serve as important resources for downstream countries in mainland Southeast Asia. The long and complicated relations between these downstream countries and China have created a complex geopolitical backdrop against which hydropower development occurs. Despite the importance and vulnerability of this region, to our knowledge, no work has explicitly investigated the potential for change in the area resulting from hydropower development, or the sources of social and environmental vulnerability associated with hydropower development.

Our objective was thus to investigate the nature of and relationships among current internal and external vulnerabilities to hydropower development in one of the Three Parallel Rivers basins, the $\mathrm{Nu}$ River. Although some small dams exist within the basin, the Nu River is one of the world's last principally unregulated major rivers. After briefly describing the human and physical geographic characteristics of the Nu River basin, we examine which characteristics of the basin's ecological and social systems influence its ability to anticipate, cope with, and recover from dam construction,

\footnotetext{
${ }^{1}$ Oregon State University, ${ }^{2}$ The World Bank, ${ }^{3}$ Hobart and William Smith Colleges, ${ }^{4}$ Chinese University of Hong Kong, ${ }^{5}$ World Resources Institute
} 
and we explore the relationships among those characteristics. We present original data on the cultures, economics, hydropolitics, and environments of the basin, drawing largely on the conceptual and analytical tools of the Integrative Dam Assessment Modelling (IDAM) framework (Brown et al. 2009) and Füssel's (2007) framework for analysis of vulnerability.

\section{STUDY AREA}

The Nu River arises on the eastern edge of the Tibetan plateau and flows south for approximately $2000 \mathrm{~km}$ in China, exiting the country through Yunnan Province's western border with Myanmar (Fig. 1). On its north-south journey within Yunnan, the river flows through the Nujiang Lisu Nationality Autonomous Prefecture (Nujiang Prefecture) and Baoshan Municipality, briefly intersecting Dali Prefecture and Lincang Prefecture along the way.

Fig. 1. Map of the study site, indicating the location of the four proposed dams.

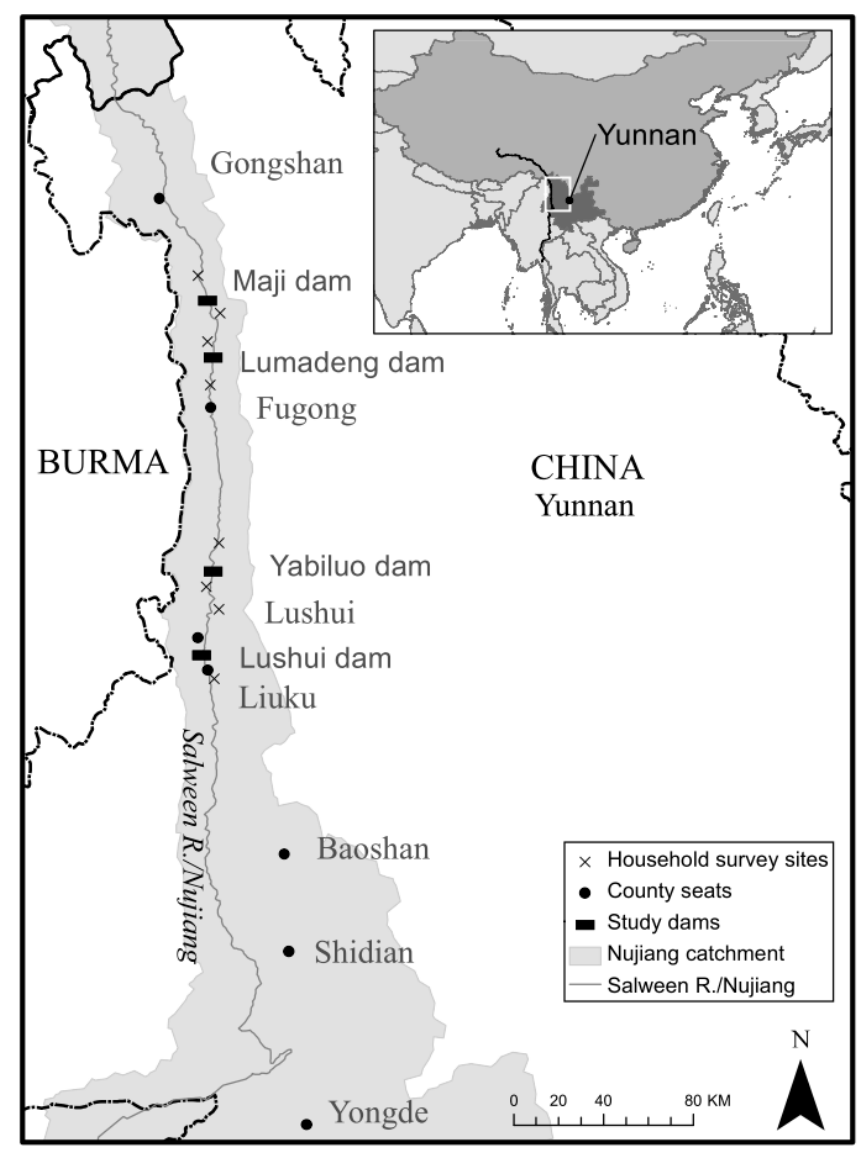

The word $n u$ means angry in Chinese, a name that accurately reflects the character of the Nu River, whose precipitous 1116$\mathrm{m}$ drop over its $621-\mathrm{km}$ stretch in Yunnan could produce a technically feasible hydropower potential of $21 \mathrm{GW}$ (Zhou and Zhang 2003). The Chinese central government's original plans for $\mathrm{Nu}$ River hydropower development called for a cascade of 13 dams with a combined installed capacity of 21 $\mathrm{GW}$ (Brown and $\mathrm{Xu} 2010$ ). Proponents of the cascade argue that the steepness of most of the gorge, volume of river flows, gradient of the river, and limited number of residents potentially displaced (roughly 56,000; Luo et al. 2005) create an ideal site for a large cascade of dams (He and Feng 2004, Magee and McDonald 2006). Opponents counter that the dams would threaten the biological and cultural diversity of western Yunnan. Furthermore, benefits of the project, i.e., a marginal increase in the reliability of power available to the China Southern Grid, would accrue to distant users in load centers as far away as Guangdong, whereas negative effects such as resettlement and inundation of already scarce farmland would fall on villagers living in the immediate vicinity of the dams and their reservoirs (He and Feng 2004, Magee and McDonald 2006).

Roughly four million people live within the $\mathrm{Nu}$ River basin in Yunnan, with approximately 500,000 living in Nujiang Prefecture. The Nu River region is home to 22 distinct ethnic groups, many of which maintain their own languages, cultural traditions, and religious practices. Ethnic minorities compose $>92 \%$ of the overall population in Nujiang Prefecture. Some of these ethnic groups are quite small, including the Derung (population of 7426), the $\mathrm{Nu}$ (population of 28,759), and the Pumi (population of 33,600; Chinese Statistical Bureau 2000). As marginalized ethnic minorities, many residents on the $\mathrm{Nu}$ River valley have limited access to the political and economic resources necessary to engage meaningfully in hydropower development discourse and planning processes (Zahran et al. 2008, Mustafa et al. 2011). Further, some three-quarters of the land area within Nujiang Prefecture consists of slopes $>25 \%$, forcing farmers to cultivate steep, marginal lands that are already prone to soil erosion and topsoil loss during heavy rains. Moreover, the level of economic development in northwest Yunnan is low, suggesting that socioeconomic vulnerabilities among the displaced populations would be acute (Brown and $\mathrm{Xu}$ 2010). Thus, resettlement may be particularly challenging for members of these small ethnic groups who would face relocation into lands they have not traditionally occupied and integration into populations with different languages, customs, and agricultural traditions.

Nine of the thirteen proposed dams are located in Nujiang Prefecture, a designated hotspot of biodiversity. In July 2003, the United Nations Educational, Scientific, and Cultural Organization (UNESCO) recognized this area for its unique value to global biodiversity by designating the Three Parallel Rivers of Yunnan Protected Areas as a UNESCO World Heritage Site. Additionally, The Nature Conservancy (TNC) and Conservation International (CI) named areas of northwest Yunnan a Biodiversity Hotspot, drawing attention to the 
Table 1. Characteristics of four proposed hydroelectric dams on the Nu River, China.

\begin{tabular}{|c|c|c|c|c|c|c|c|}
\hline Dam site & Dam height $(\mathrm{m}) \dagger$ & $\begin{array}{c}\text { Reservoir area } \\
\left(\mathrm{km}^{2}\right)\end{array}$ & $\begin{array}{c}\text { Installed } \\
\text { capacity }(\mathrm{MW}) \dagger\end{array}$ & $\begin{array}{c}\text { Number of } \\
\text { people } \\
\text { displaced } \$\end{array}$ & $\begin{array}{c}\text { Cost of } \\
\text { resettlement } \\
\text { (billion RMB)§ }\end{array}$ & $\begin{array}{l}\text { Total project } \\
\text { investment } \\
\text { (billion } \mathrm{RMB} \text { ) }\end{array}$ & $\begin{array}{c}\text { Annual } \\
\text { commercial value } \\
\text { of hydropower } \\
\text { (billion RMB)! }\end{array}$ \\
\hline Maji & 300 & $16.5 \dagger-66.2 \mathbb{I}$ & 4200 & 19,830 & 1.0 & 18.4 & 5.9 \\
\hline Lumadeng & 165 & 2.9 đI $-11.2 \pi$ & 2000 & 6092 & 0.3 & 9.1 & 3.2 \\
\hline Yabiluo & 133 & $1.8 \dagger-8.9 \mathrm{~d}$ & 1800 & 3982 & 0.2 & 6.0 & 2.9 \\
\hline Lushui & 175 & $4.0 \dagger-18.5 \llbracket$ & 2400 & 6190 & 0.3 & 8.8 & 4.0 \\
\hline Total & & & 10,400 & 36,094 & 1.8 & 42.4 & 16.0 \\
\hline
\end{tabular}

$\dagger$ From Dore and Yu (2004).

¥Figures for number of people displaced represent currently available government estimates (He et al. 2007, Magee and McDonald 2009); however, as noted in Results: Biophysical domain, there is considerable uncertainty about reservoir sizes, which could affect the figures for displaced population. $\S$ Resettlement costs are based on a projected minimum of 50,000 RMB/person (Yunnan Redevelopment Commission). The exchange rate is 1 USD $=6.6$ RMB.

TThe annual commercial value of hydropower is based on current government estimates, but the lifespan of the hydropower projects and future electricity prices are uncertain.

IIModeled by Kibler (2011).

region's 3500 plant species and eight endangered animal species. A high proportion of endemic species characterize the vast ecological diversity of northwest Yunnan (Xu and Wilkes 2004), and many species are protected at the provincial or state level or are listed on the International Union for Conservation of Nature (IUCN) red list of threatened species (IUCN 2001). Although comprehensive biological monitoring currently does not occur in the Nu River basin, there are 48 known species of fish in the Nu River, 70\% of which are endemic and four of which are listed as endangered (Magee and McDonald 2006).

Of the 13 proposed projects in the Nu River cascade (Magee 2006), we focus our analysis on four that capture a range of variation in dam size and geographic locations (Table 1). Relative to the well-known Three Gorges project, which inundated $630 \mathrm{~km}^{2}$ (Wang 2002), and the global range of reservoir areas $\left(10^{-3}\right.$ to $10^{4.5} \mathrm{~km}^{2}$; Takeuchi $\left.1997 \mathrm{a}\right)$, the footprints of these four projects are not exceptionally large (Table 1). However, relative to other known dams in China (International Commission on Large Dams 2003), all four of the study dams on the Nu River fall within the 99th percentile with respect to installed electrical capacity, and at least the 66th percentile with respect to the number of people to be resettled (Table 2). Thus, the magnitudes of benefits and costs associated with the proposed dams are not insignificant compared to those of China's existing dams.

\section{METHODS}

\section{Background on vulnerability as a framework for analysis}

We analyzed the relationships between the proposed hydropower development on the $\mathrm{Nu}$ River and its people, environment, and geopolitics in the context of vulnerability. Although the definition and characterization of vulnerability is still debated (Ionescu et al. 2009), its importance in understanding human-environment interactions (e.g., natural hazard risk, food security, and climate change) has been recognized by many (e.g., Timmerman 1981, Liverman 1990, Gunderson and Holling 2002, Brooks 2003, Turner et al. 2003, Kasperson et al. 2005, Adger 2006, Janssen et al. 2006, Füssel 2007, Janssen 2007, Miller et al. 2010), and is relevant to decision-making about dams (World Commission on Dams 2000).

Important but limited research has stressed the need to consider vulnerable ecosystems, species, and peoples associated with hydropower development, though again without clear definition of the concepts (King et al. 2007). Previous research has tended to focus on the socioeconomic vulnerability of human populations affected by hydropower development. For example, it has been acknowledged that poor, marginalized, minority peoples are particularly vulnerable to the effects of dams and displacement (Cernea 2000, Zahran et al. 2008, Mustafa et al. 2011), and that poor farmers from minority ethno-linguistic groups are especially vulnerable to challenges resulting from resettlement (Brown et al. 2009). From a geopolitical perspective, researchers have analyzed hydropolitical vulnerability as the potential for political dispute in river basins where the water resources are shared among stakeholders (McNally et al. 2009).

The literature includes analyses of development-related socioeconomic and biophysical vulnerabilities, as well as the inter-relationships between those vulnerabilities. For example, Twigg (2007) and Mustafa et al. (2011) assess generalized social vulnerability to development, characterized by variables such as health, income, education, wealth, social networks, knowledge, and minority status. Vulnerability is also defined in the evaluation of ecosystems, including 
Table 2. Projected hydroelectric capacity and number of people that would need resettlement for four proposed hydroelectric dams on the Nu River, China, relative to established dams throughout China.

\begin{tabular}{|c|c|c|c|c|c|c|c|}
\hline & \multicolumn{3}{|c|}{ Percentile (relative to dams across China) } & \multicolumn{4}{|c|}{ Dam site } \\
\hline & $33 \mathrm{rd}$ & 66th & 99th & Maji & Lumadeng & Yabiluo & Lushui \\
\hline Installed capacity $(\mathrm{MW}) \dagger$ & 1 & 6 & 1400 & 4200 & 2000 & 1800 & 2400 \\
\hline $\begin{array}{l}\text { Resettlement (number of } \\
\text { people) } \neq\end{array}$ & 200 & 896 & 274,237 & 19,830 & 6092 & 3892 & 6190 \\
\hline
\end{tabular}

$\dagger$ World Register of Dams online database: http://www.icold-cigb.org/GB/World register/world register.asp.

$\dagger$ He et al. (2007), Magee and McDonald (2009).

responses to stresses induced by climate change (McCarthy et al. 2001, Schröter et al. 2005), land-use change (Wickham et al. 2000, Metzger et al. 2005), exotic species invasions (Stohlgren et al. 2002, Gritti et al. 2006), and groundwater contamination (Loague 1994). Researchers have proposed methods to standardize the assessment of environmental vulnerability (Villa and McLeod 2002), though proposed assessments lack general applicability, targeting specific systems and their associated stressors. Recent work (Leichenko and O'Brien 2002, Kasperson et al. 2005, Eakin and Luers 2006, McLaughlin and Dietz 2008) emphasizes the importance of considering socioeconomic, environmental, and geopolitical vulnerabilities simultaneously because of the synergistic effects of most development. However, integrated perspectives seeking to understand the inter-relationships between vulnerabilities across multiple domains have not yet been applied to investigate hydropower development. Thus, the following important and complicated tasks remain: identifying sources of vulnerability; investigating relationships between elements of vulnerability; and developing appropriate support mechanisms for social, ecological, and political groups vulnerable to hydropower development.

In our analysis, we adopted Füssel's (2007) interdisciplinary vulnerability framework, which is based on six dimensions: (1) the temporal reference, (2) whether vulnerability factors are endogenous or exogenous to the system, (3) the knowledge domain, (4) the vulnerable system, (5) the attribute of concern, and (6) the hazard. We considered the current conditions as our temporal reference, the $\mathrm{Nu}$ River basin as our vulnerable system, and hydropower development as the hazard, with all other dimensions defined in Table 3. We first characterized the $\mathrm{Nu}$ River system domains (biophysical, socioeconomic, and geopolitical) using a set of measures (henceforth referred to as vulnerabilities; Table 3) that influence the system's ability to anticipate, cope with, and recover from dam construction. We then examined relationships among vulnerabilities and across domains.

\section{Knowledge domains}

Our knowledge domains are based on the three pillars (biophysical, socioeconomic, geopolitical) of sustainability identified by the 1993 United Nations Conference, and on the conceptual and analytical approach defined by the IDAM framework (Brown et al. 2009). For each knowledge domain, we present three measures of vulnerability.

\section{Biophysical domain}

We analyzed the vulnerability of the biophysical domain to describe the potential for dams: (1) to modify biogeochemical, thermal, and sediment regimes by altering the residence time of water through the reservoir reach, (2) to trigger landscape instability with emphasis on seismicity, and (3) to eliminate habitat for vulnerable species. Analysis of these metrics is based on previously published estimates of reservoir volume and extent (Dore and $\mathrm{Yu}$ 2004) as well as our modeled estimates, derived from analysis of Advanced Spaceborne Thermal Emission Radiometer (ASTER) 30-m Digital Elevation Models (ASTER 2009) and incorporating uncertainty (Kibler 2011). Thus, we present a range of values for each measure, corresponding to the range of estimates in modeled and reported reservoir volume and surface area. Uncertainty analysis incorporates ambiguity in the final location of the proposed dams and in the variability of the operations schedule, both of which influence the volume and surface area of reservoirs (see Kibler 2011 for further details).

To represent reservoir sensitivity to modifications in biogeochemical cycling, water temperature, and sediment transport (Friedl and Wüest 2002), we analyzed potential changes to residence time in reaches that would be inundated by the proposed dams (henceforth referred to as reservoir reaches). We calculated residence time through reservoir reaches, evaluating both pre-dam and post-dam conditions as the ratio of reach volume $\left(\mathrm{m}^{3}\right)$ to the annual average of the daily outflow $\left(\mathrm{m}^{3} / \mathrm{d}\right)$, and reported percent change between pre-and post-dam reaches. We note that residence time represents the potential sensitivity of the reservoir reach and does not predict the response of downstream channels. River biogeochemistry of the downstream reaches is likely strongly influenced by the variability of the flow regime (Junk et al. 1989, Poff et al. 1997; Postel and Richter 2003); however, information on reservoir operations, which is not publicly available, is required for analysis of flow variability; thus, we limited the spatial extent of our analysis to the reservoirs. 
Table 3. Framework for characterizing vulnerability for the Nu River case study of four proposed hydroelectric dams. Consistent with Füssel (2007), sphere is identified as internal or external depending on whether they are properties of the vulnerable system or are factors outside of that system, respectively.

\begin{tabular}{|c|c|c|c|c|}
\hline Domain & Vulnerability measure & Description & Relationship to dam as a stress & Sphere \\
\hline \multirow[t]{3}{*}{ Biophysical } & Retention time & $\begin{array}{l}\text { Percent change in residence time of water } \\
\text { through reservoir reach (units: \%) }\end{array}$ & $\begin{array}{l}\text { Describes the hydrological sensitivity of the } \\
\text { system to modified biogeochemical, } \\
\text { temperature, and sediment regimes }\end{array}$ & Internal \\
\hline & Landscape stability & $\begin{array}{l}\text { Depth and volume of reservoir; distance to } \\
\text { active faults (units: seismic index) }\end{array}$ & $\begin{array}{l}\text { Describes the potential for dams to trigger } \\
\text { seismic activity }\end{array}$ & Internal \\
\hline & Habitat for sensitive species & $\begin{array}{l}\text { Amount of conservation land inundated } \\
\text { (units: } \mathrm{km}^{2} \text { ) }\end{array}$ & $\begin{array}{l}\text { Describes potential impacts on rare species } \\
\text { or species of concern }\end{array}$ & Internal \\
\hline \multirow[t]{3}{*}{ Geopolitical } & $\begin{array}{l}\text { International institutional } \\
\text { capacity }\end{array}$ & $\begin{array}{l}\text { Treaty coding for specific water management } \\
\text { capacities and people in the basin (units: } \\
\text { normalized score relative to other basins) }\end{array}$ & $\begin{array}{l}\text { Describes the capacity for the international } \\
\text { political system of the basin to adapt to and } \\
\text { recover from the stress of dam construction }\end{array}$ & External \\
\hline & $\begin{array}{l}\text { Hydro-political stability } \\
\text { (international) }\end{array}$ & $\begin{array}{l}\text { International water event intensity scale } \\
\text { (units: normalized score relative to other } \\
\text { basins) }\end{array}$ & $\begin{array}{l}\text { Characterizes the stability of the international } \\
\text { hydro-political system in the recent past }\end{array}$ & External \\
\hline & $\begin{array}{l}\text { Hydro-political stability } \\
\text { (domestic) }\end{array}$ & $\begin{array}{l}\text { Domestic water event intensity scale (units: } \\
\text { normalized score relative to other basins) }\end{array}$ & $\begin{array}{l}\text { Characterizes the stability of the domestic } \\
\text { hydro-political system in the recent past }\end{array}$ & Internal \\
\hline \multirow[t]{3}{*}{ Socioeconomic } & Income and wealth & $\begin{array}{l}\text { Household income and housing values } \\
\text { compared to the watershed average (units: } \\
\text { currency) }\end{array}$ & $\begin{array}{l}\text { Describes the economic conditions of } \\
\text { potentially affected human populations }\end{array}$ & Internal \\
\hline & Local culture & $\begin{array}{l}\text { Index of ethnic minorities as a percentage of } \\
\text { the population; proportion of household } \\
\text { heads with literacy in Chinese (units: \%) }\end{array}$ & $\begin{array}{l}\text { Describes the cultural characteristics of } \\
\text { potentially affected populations }\end{array}$ & Internal \\
\hline & Social cohesion & $\begin{array}{l}\text { Index of community trust and cohesiveness; } \\
\text { participation in village activities; borrowing } \\
\text { and lending networks; labor sharing } \\
\text { networks (units: \%; score on five-point scale) }\end{array}$ & $\begin{array}{l}\text { Describes the social characteristics of } \\
\text { potentially affected populations }\end{array}$ & Internal \\
\hline
\end{tabular}

Although reservoirs are known to destabilize hill slopes by triggering and intensifying landslides (Fourniadis et al. 2007), we focused our evaluation of landscape stability on the potential for the reservoirs to induce and intensify seismicity (Talwani 1997, Chen and Talwani 1998, Gupta 2002). Empirical data suggest that reservoir depth and volume, along with proximity of reservoirs to active faults, may influence the likelihood of reservoir-triggered seismicity (Baecher and Keeney 1982). We combined these three parameters by multiplying maximum reservoir depth by maximum reservoir volume and dividing by minimum distance to a mapped active fault to produce a single index such that larger values reflect greater vulnerability to reservoir-trigger seismicity.

We characterized biodiversity vulnerability as the area $\left(\mathrm{km}^{2}\right)$ of designated conservation land that the proposed reservoirs would inundate. We adopted conservation designations from areas of global importance for preserving biodiversity as identified within the Nu River basin by UNESCO, TNC, and $\mathrm{CI}$; and site-scale Key Biodiversity Areas (KBAs) delineated at the regional scale (Langhammer et al. 2007).

\section{Socioeconomic domain}

To assess socioeconomic vulnerability in the Nu River basin, we conducted household surveys within Nujiang Prefecture in 2009. Surveys took place in two counties (Fugong and Lushui) encompassing 13 townships and 20 villages (Fig. 1) and including communities located both upstream and downstream of the four proposed dam sites. We conducted both quantitative and qualitative surveys, with a total sample of 405 households, to provide information on a range of issues related to income, livelihood activities, ethnic and cultural identity, community participation, and education. Approximately $10 \%$ of households participated in the qualitative interview, which included open-ended questions about the perceived effects of the dams. To characterize the vulnerability of the households that would be affected by the projects, we summarized measures of income and wealth, minority status, and social cohesion based on the household surveys. Each of these measures is well documented as a key indicator of vulnerability to development-related stresses (e.g., Twigg 2007).

We characterized income and wealth, which are key indicators of vulnerability to stresses of all kinds (e.g., Mustafa et al. 2011), as (1) median per capita annual income, including agriculture, wage labor, and direct government assistance, and (2) median estimated home value as a proxy for household wealth. We assessed vulnerability associated with local culture, including socio-cultural background and ethnicity (Zahran et al. 2008), as the proportion of surveyed households who self-identify as a minority and the proportion of household heads who are literate. Finally, we estimated measures of 
social cohesion, or the degree to which community members maintain interdependence with one another through relationships of trust and reciprocity. Such relationships reinforce a community's ability to adapt to changes or stresses (Field 2003). As a measurement of social cohesion, we reported villagers' agricultural labor-sharing activities with their neighbors and their level of participation in organizations such as village committees.

\section{Geopolitical domain}

For the geopolitical domain, our analysis occurred at the scale of the river basin. Because our unit of analysis was the river basin and we investigated four dams within the same basin, there is, by definition, no variability in geopolitical indicators of vulnerability. However, this lack of variability does not indicate that the geopolitical context is unimportant. To assess the geopolitical vulnerability of the $\mathrm{Nu}$ River basin, we reported qualitatively on the geopolitical features of the $\mathrm{Nu}$ River basin and compared these features to river basins worldwide. The geopolitical backdrop against which hydropower development occurs in the $\mathrm{Nu}$ River basin fundamentally shapes and is shaped by the degree of vulnerability among characteristics of the biophysical and socioeconomic domains.

We reported three aspects of the hydropolitical system that reflect vulnerability to dam construction: international hydropolitical stability, domestic hydro-political stability, and international institutional capacity as it relates to water resources management. The first two indicators describe the historical level of cooperation and conflict over water resources within the basin at the inter- and intra-national levels. The third indicator describes the capacity of existing transboundary hydro-political institutions to cope with physical or institutional change in the basin.

We first characterized international hydropolitical stability by describing historical patterns of interaction over water resources within the basin using Oregon State University's Basins at Risk scale. Following established methods (Yoffe 2001, Yoffe et al. 2003, Fesler 2007), we used data from the Transboundary Freshwater Dispute Database (Wolf 1999) to construct a timeline of hydro-political events for the Nu River basin at the international level. Yoffe et al. (2003:1110) define hydro-political events as "instances of conflict and cooperation that occur within an international river basin, that involve the nations riparian to that basin, and that concern freshwater as a scarce or consumable resource... or as a quantity to be managed." To reflect the level of conflict or cooperation, we scored each event on a scale ranging from -7 to +7 . We refer to this score as the event intensity. Negative scores reflect conflict, positive scores reflect cooperation, and the absolute value of the score indicates the intensity of the event. A score of -5 or +5 has greater intensity than a score of -2 or +2 . For example, mild verbal expressions of support score as +1 , whereas enactment of a transboundary water treaty scores at +6 . The underlying logic is that the signing of a treaty reflects a greater intensity of cooperation than does an expression of verbal support. Similarly, a hostile military action is a more intense conflict than is verbal disapprobation.

Analysis of domestic hydro-political stability builds upon methods used to assess international hydro-political stability. Fesler (2007) adapted the event intensity scoring methodology of Yoffe (2001) to the domestic context, with the domestic scale ranging from -5 to +5 . We summarized the results of this analysis by reporting the mean annual event intensity.

For both domestic and international analyses of hydropolitical stability, we used event data (for example, see Table 4), available from the Transboundary Freshwater Dispute Database, through 2010. Pertinent data include riparian nations involved, the original citation or source documenting the event, the primary issue, a brief event summary, and the event intensity scale. For our analysis, we used both existing event data and new events added to the database following an extensive search of both Chinese and international media. The search included local newspapers, blogs, and scholarly publications documenting every reported domestic hydropolitical event that occurred in relation to the Nu River. We acknowledge, however, that it is unlikely that all hydropolitical events are reported in the media and that the domestic event chronology may present a biased sample of interactions. The Chinese government actively engages in censorship of the media, and journalists widely self-censor based on the political sensitivities of a particular time and place. Therefore, the sample of events likely underestimates the level of conflict within the Nu River basin in China.

Finally, we characterized the presence and features of treaties or River Basin Organizations (RBOs), which enable riparian nations jointly to manage international rivers. RBOs and treaties are two manifestations of transboundary hydropolitical institutional capacity because of their potential to attenuate stress and distribute costs and benefits resulting from dam construction. We characterized the institutional capacity for international water management by examining five features of a transboundary hydro-political system (De Stefano et al. 2012): (1) the existence of an international water treaty, (2) a mechanism for allocating benefits (water or hydropower) among nations, (3) a mechanism for managing flow variability, (4) a mechanism for conflict resolution, and (5) the existence of an RBO. Because it is possible that not all nations in an international basin are party to an existing treaty, De Stefano et al. (2012) subdivide transboundary river basins into basin-country units (BCUs). A BCU is that part of a basin that lies within a particular country. The $\mathrm{Nu}$ (Salween) River, for example, has three BCUs: those parts of the basin in China, Myanmar, and Thailand. We scored each BCU on a scale of zero to five, where the presence of each indicator contributes 
Table 4. Examples of transboundary events. $\dagger$

\begin{tabular}{|c|c|c|c|c|c|c|}
\hline Basin name & $\begin{array}{c}\text { Countries } \\
\text { involved }\end{array}$ & Primary issue & Date of event & Event summary & BAR scale: & Source \\
\hline Salween & $\begin{array}{l}\text { Thailand, } \\
\text { Myanmar }\end{array}$ & $\begin{array}{l}\text { Infrastructure } \\
\text { and } \\
\text { development }\end{array}$ & $\begin{array}{l}\text { March 6, } \\
2007\end{array}$ & $\begin{array}{l}\text { Ethnic groups (Thai and Mynamar) protest the Thai } \\
\text { government to stop building hydroelectric dams on the } \\
\text { Salween River, which would displace people in both } \\
\text { countries }\end{array}$ & -1 & $\begin{array}{l}\text { Thai press } \\
\text { reports }\end{array}$ \\
\hline Salween & $\begin{array}{l}\text { Thailand, } \\
\text { Myanmar }\end{array}$ & $\begin{array}{l}\text { Hydropower } \\
\text { and } \\
\text { hydroelectricity }\end{array}$ & $\begin{array}{c}\text { August 4, } \\
2004\end{array}$ & $\begin{array}{l}\text { Thailand and Myanmar agree to set up a joint venture for the } \\
\text { construction of five hydropower dams in the Salween River } \\
\text { basin, beginning with Tasang dam }\end{array}$ & 4 & $\begin{array}{l}\text { Wolf and } \\
\text { Newton } \\
(2008)\end{array}$ \\
\hline
\end{tabular}

one point to the score; the cumulative score of these indicators reflects the overall hydro-political institutional capacity of a BCU. Finally, we compared the Nu River basin's treaty score to those of other basins worldwide using a percentile ranking approach.

\section{RESULTS}

\section{Biophysical domain}

\section{Residence time}

The change in residence time through the reservoir reach varies considerably across the projects, from a minimum of an approximately $2600 \%$ increase at Lumadeng to a maximum of an approximately 32,000\% increase at Lushui (Table 5). These percentages represent absolute changes on the time scales of $0.0005-0.15 \mathrm{yr}$. These effects are smaller than the mean change in residence time $(0.21 \mathrm{yr})$ that Vörösmarty et al. (2003) estimated for 633 of the world's largest reservoirs (storage capacity $\left.>0.5 \mathrm{~km}^{3}\right)$. Thus, relative to global $(0.001-$ $23.9 \mathrm{yr}$ ) and Asian (0.7-1.2 yr) populations of dams, the $\mathrm{Nu}$ River dams represent relatively small potential changes to river biogeochemistry. However, in considering these projected modifications to the river's residence time relative to the time scales of biogeochemical processes and material or pollutant inputs to rivers, both of which occur at the subdaily scale, the system is likely to become more sensitive to external stresses (e.g., chemical and nutrient pollution; Walker 1983, Jiemin et al. 2003), thereby contributing to the river's vulnerability with regard to those stresses.

A comparison of the four reservoirs indicates that the Maji reservoir would result in the greatest absolute change in residence time because of its relative height, length, and volume. However, the second largest reservoir (volumetrically), Lushui, is projected to impose the largest percent increase in residence time on the Nu River. These differences in residence times are a function of reservoir geometry controlled by both dam height and valley configuration, which has a strong geographic trend in the $\mathrm{Nu}$ River. For example, the river gradient at the most upstream site (Maji) is only $0.001 \mathrm{~m} / \mathrm{m}$, whereas the gradient at the most downstream site (Lushui) is $0.005 \mathrm{~m} / \mathrm{m}$. Associated with the lower gradient and greater dam height, the length of the Maji reservoir is greater than the length of the other three reservoirs. This configuration results in a pre-dam residence time at Maji that is much longer than the others. In contrast, the reservoir reach at Lushui is short relative to the other sites because of the steeper river gradient in this reach as well as the low relative height of the dam. With the short pre-dam residence time at Lushui, the percent increase in residence time is relatively large when compared to the other sites. Thus, the greatest absolute change in residence time would occur at the Maji reservoir, though the percent change in reservoir time is greatest at Lushui, reflecting the importance of geographic setting in establishing the effect of a dam to a river's vulnerability to external stresses.

Notably, these results span a wide range of residence times, which is a function of uncertainty and variability in reservoir volumes (Table 5). Uncertainties related to final dam locations and variability within reservoir operational ranges exert a strong influence on the hydraulics, hydrology, and geochemistry of the reservoirs and downstream reaches.

\section{Landscape stability}

Vulnerability of the landscape due to reservoir-induced seismicity predictably varied with depth and volume of the reservoirs. The reservoir at Maji has the greatest potential to induce seismic activity because of its high relative depth and volume. Of the four reservoirs, Maji is also located closest to active faults, although the distance to active faults varies little across the four reservoirs. Reservoir size thus accounts for most of the variability in the potential for reservoir-induced seismicity.

Elsewhere, seismic activity has been influenced by reservoirs far smaller than Maji. For comparison, Zipingpu Reservoir, believed to have exacerbated seismic conditions leading to the 2008 Wenchuan earthquake in Western Sichuan Province, has a maximum depth and volume of $155 \mathrm{~m}$ and $320 \times 10^{6} \mathrm{~m}^{3}$, respectively, and was located within $1 \mathrm{~km}$ of the ruptured 
Table 5. Projected biophysical vulnerabilities to proposed hydropower development based on modeled reservoirs of the Nu River, China.

\begin{tabular}{|c|c|c|c|c|c|c|c|c|c|c|c|c|c|}
\hline \multirow[t]{2}{*}{ Dam site } & \multicolumn{2}{|c|}{$\begin{array}{c}\text { Change in residence } \\
\text { time }(\%)\end{array}$} & \multicolumn{2}{|c|}{$\begin{array}{l}\text { Absolute change in } \\
\text { residence time } \\
\text { (days) } \dagger\end{array}$} & \multicolumn{2}{|c|}{$\begin{array}{l}\text { Reservoir storage } \\
\text { volume }\left(10^{6} \mathrm{~m}^{3}\right)\end{array}$} & \multirow[t]{2}{*}{$\begin{array}{l}\text { Reservoir } \\
\text { depth } \\
\text { (m) }\end{array}$} & \multicolumn{2}{|c|}{$\begin{array}{l}\text { Distance to active } \\
\text { faults }(\mathrm{km})\end{array}$} & \multicolumn{2}{|c|}{ Seismicity index } & \multicolumn{2}{|c|}{$\begin{array}{l}\text { Conservation area } \\
\text { inundated }\left(\mathrm{km}^{2}\right)\end{array}$} \\
\hline & Min & $\operatorname{Max}$ & Min & Max & Min & Max & & Min & Max & Min & Max & Min & Max \\
\hline Maji & 13,430 & 24,376 & 14 & 55.1 & 1552 & 6075 & 300 & 1 & 1 & 0.3 & 1 & 28 & 71 \\
\hline Lumadeng & 2632 & 17,350 & 0.2 & 3.4 & 22 & 397 & 165 & 1 & 3 & 0.0007 & 0.04 & 3 & 11 \\
\hline Yabiluo & 7741 & 13,319 & 1 & 3.4 & 127 & 427 & 133 & 1 & 1 & 0.009 & 0.03 & 5 & 9 \\
\hline Lushui & 10,526 & 31,962 & 1.6 & 8.8 & 206 & 1143 & 175 & 1 & 1 & 0.01 & 0.1 & 7 & 19 \\
\hline Minimum & 2632 & 13,319 & 0.2 & 3.4 & 22 & 397 & 133 & 1 & 1 & 0.0007 & 0.03 & 3 & 9 \\
\hline Maximum & 13,430 & 31,962 & 14 & 55.1 & 1552 & 6075 & 300 & 1 & 3 & 0.3 & 1 & 28 & 71 \\
\hline
\end{tabular}

$\dagger$ It is important to note that these time scales are skewed by the volume of the reservoir. That is, a 0.15 -yr change in residence time does not directly represent $32,000 \%$ change. Maji, with the largest reservoir volume, has the greatest absolute time change ( $0.15 \mathrm{yr})$, whereas Lushui has the greatest percentage change $(32,000 \%)$. Lushui's absolute change is $0.024 \mathrm{yr}$.

Beichuan fault (Klose 2012). The configuration at Zipingpu Reservoir leads to a seismicity index of 0.03 , which is similar to that calculated for Yabiluo and lower than those calculated for Maji, Lumadeng, and Lushui.

\section{Habitat diversity}

Projected impacts to vulnerable habitat, designated as conservation area inundated, vary with reservoir size and position of the reservoir relative to protected conservation areas (Table 5). As the largest of the four dams, we project that Maji would inundate the greatest land area (between 16 and $66 \mathrm{~km}^{2}$ ) of vulnerable habitat. However, Maji, as the most geographically isolated of the four study sites, is also the closest in proximity to conservation areas, making its contribution to the vulnerability of the area greater than that of the other projects. Thus, although reservoir size is a primary factor influencing effects to ecosystem vulnerability, proximity to designated conservation areas is also an important contributing factor.

\section{Socioeconomic domain}

\section{Income and wealth}

Within the survey sample, the median household income is approximately RMB 785/yr (USD 118/yr), or RMB 2.15/d (USD 0.33/d; Table 6). Of the entire sample, approximately $70 \%$ of surveyed households received poverty alleviation subsidies from the central government in 2009 (Table 6). In the two upstream dam sites (Maji and Yabiluo), 90\% of households received subsidies. More than half of the surveyed households rely solely on agriculture for income, which stems from the lack of non-farm opportunities in the area.

In terms of wealth, the largest asset for most people in rural China is their home. However, there is considerable variation in housing values within the survey sample, ranging from RMB 41,058 in Lushui to RMB 19,306 in Maji (Table 6). This variation in housing values is important for understanding socioeconomic vulnerability to hydropower development because China's current compensation policies for resettled populations are based on housing values. On September 1, 2006, the State Council, China's chief legislative body, adopted the Regulations on Land Acquisition Compensation and Resettlement of Migrants for Construction of Large and Medium Scale Water Conservancy and Hydropower Projects, which stipulate that resettled villagers are to receive 16-times the value of their average annual income in addition to compensation for housing of the "same scale, same standard, and same function" (Brown and Xu 2009:25). Because displaced farmers lose both their source of income in agricultural land as well as the bulk of their material wealth to reservoir inundation, they must rely primarily on this compensation to rebuild their livelihood. Given the variation in housing values observed in our survey, compensation amounts and the capacity to cope with coincident stressors will likely vary considerably across communities. Incomes and housing values in the northern part of the basin (near the Maji and Lumadeng dam sites) are markedly lower, resulting in more acute vulnerability for these communities.

\section{Local culture}

China considers itself a unified, multiethnic state (tongyi duo minzu guojia). The minority nationalities, whose populations numbered 114 million as of the 2010 census, represent a special development problem for the central government. On the one hand, minority status provides justification for targeted development, economic assistance, educational subsidies, and national welfare policies. On the other hand, many perceive high concentrations of minority nationalities as a barrier to achieving development at a level that is consistent with the national average.

All areas of Nujiang Prefecture are home to a predominantly Lisu minority population. While the percentage of minority populations is high for all sites, $100 \%$ of the study participants 
Table 6. Projected socioeconomic vulnerabilities of the Nu River, China, to hydropower development. Standard deviations in parentheses.

\begin{tabular}{|c|c|c|c|c|c|c|c|}
\hline Dam site & Income in $\mathrm{RMB} \dagger$ & $\begin{array}{l}\text { Median housing } \\
\text { value in RMB }\end{array}$ & $\begin{array}{l}\text { Ethnic minority } \\
\qquad(\%) \ddagger\end{array}$ & $\begin{array}{c}\text { Literate } \\
\text { household heads } \\
(\%)\end{array}$ & $\begin{array}{l}\text { Households } \\
\text { receiving farm } \\
\text { help in past } 12 \\
\text { mo }(\%)\end{array}$ & $\begin{array}{l}\text { Households } \\
\text { giving farm help } \\
\text { in past } 12 \text { mo } \\
(\%)\end{array}$ & $\begin{array}{c}\text { Average level of } \\
\text { participation in } \\
\text { village activities } \$\end{array}$ \\
\hline Maji & $638(2710)$ & $10,000(28,730)$ & 100 & 51 & 28.3 & 27.3 & $1.20(0.14)$ \\
\hline Lumadeng & $519(646)$ & $15,000(23,095)$ & 83.7 & 59 & 51 & 52 & $1.19(0.20)$ \\
\hline Yabiluo & $1325(3091)$ & $30,000(49,032)$ & 96 & 58 & 62 & 61 & $1.29(0.28)$ \\
\hline Lushui & 944 (1325) & $30,000(46,372)$ & 94.5 & 64 & 45.4 & 38.9 & $1.30(0.24)$ \\
\hline Entire sample & $784(2228)$ & $20,000(39,771)$ & 94 & 58 & 46.7 & 44.7 & $1.25(0.23)$ \\
\hline
\end{tabular}

in Maji, the northernmost area of the survey sample, are of the Lisu ethnicity (Table 6). One of the key challenges for minority groups is limited literacy in Mandarin Chinese, leaving minority households at a disadvantage in business opportunities, networking, and off-farm economic activities. Most significantly, in Nujiang Prefecture, literacy decreases from south to north as communities become increasingly geographically isolated. The lack of literacy reflects diminished economic opportunity as well as diminished capacity to participate in public hearings and other official activities related to the hydropower projects.

\section{Social cohesion}

Maji, the northernmost community, stands out for its low social cohesion in comparison to the other communities. A relatively small percentage of households report giving (28\%) or receiving (27\%) farm help in the past 12 months (Table 6). Furthermore, Maji's average level of participation in village activities is lower than that in other communities, although the size of the difference is small (Table 6). Because social networks often help to buffer households from stresses such as resettlement, Maji can be considered more vulnerable than the other communities with regard to social cohesion.

\section{Geopolitical domain}

\section{International institutional capacity}

None of the formalized mechanisms for water management identified by De Stefano et al. (2010) currently exist among or between any of the $\mathrm{Nu}$ (Salween) River basin's riparian nations (China, Myanmar, and Thailand), which suggests limited hydro-political institutional capacity. An absence of formalized management arrangements is not, however, uncommon. Within the set of all transboundary river basins worldwide, $47 \%$ of BCUs lack any formalized mechanisms, and approximately $75 \%$ of BCUs have three or fewer of the five capacity mechanisms. However, although the basins do not share any water management agreements, there are bilateral investment agreements between Myanmar and Thailand, and between China and Thailand. These investment agreements provide financing to develop hydropower projects along the Salween River as it flows through Myanmar (Wolf and Newton 2009) at, for example, the Hat Gyi and Ta Sang dam sites. Although these are financing and construction agreements, rather than management agreements, they indicate opportunity for cooperation within the Salween basin.

\section{International hydro-political stability}

Our results indicate that more conflict occurred in the Nu River basin from 2000 to 2010 than in the period from 1989 to 1999 , as illustrated by an increasing share of the total annual transboundary events that are conflictive rather than cooperative (Fig. 2). Furthermore, the trajectory of the average annual transboundary event intensity (Fig. 3) trends toward more conflictive over time, and our examination of the content of individual events (Transboundary Freshwater Dispute Database 2012) reveals that many instances of conflict are directly attributable to China's proposed dams.

China initially began soliciting development proposals for the $\mathrm{Nu}$ River in 1999 and formally announced plans for a 13-dam cascade in 2003 (Brown and Xu 2010). We identified 20 hydro-political events occurring in or after 1999. Of those, 14 are conflictive events, and with one exception, all of the conflictive events are related directly to dam construction. One example of a conflictive event typical of this time period is the submission of a letter of protest to the Chinese ambassador in Bangkok by more than 80 Thai public interest groups in March 2003 (Wolf and Newton 2009). The initiating actors are generally public interest groups protesting the potential humanitarian and environmental costs of the dams.

Despite the presence of hydro-political conflict, there are several reasons to believe that the Chinese dams proposed in western Yunnan will not lead to escalating hydro-political conflict at the international scale. First, the intensity of the conflictive events we have documented thus far is low (Fig. 
3). Only one of the 14 conflictive hydro-political events since 1999 escalated beyond mild protests or verbal expressions of discontent, and this event was not related to dam construction. Second, those engaging in conflict do not represent state governments. Non-official protests in this region rarely spill across the national borders because non-government actors are generally trying to influence their own government's actions and/or have little influence across international boundaries. Finally, the three riparian state governments continue to engage in cooperative behavior.

Fig. 2. Number of conflictive and cooperative events per year in the Salween River basin.

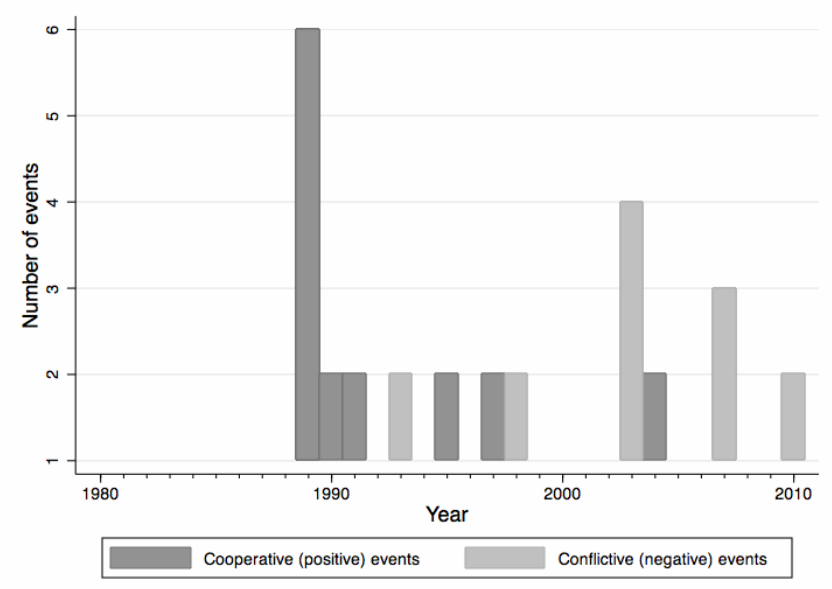

Fig. 3. Average intensity of transboundary interactions over water resources in the Salween River basin over time.

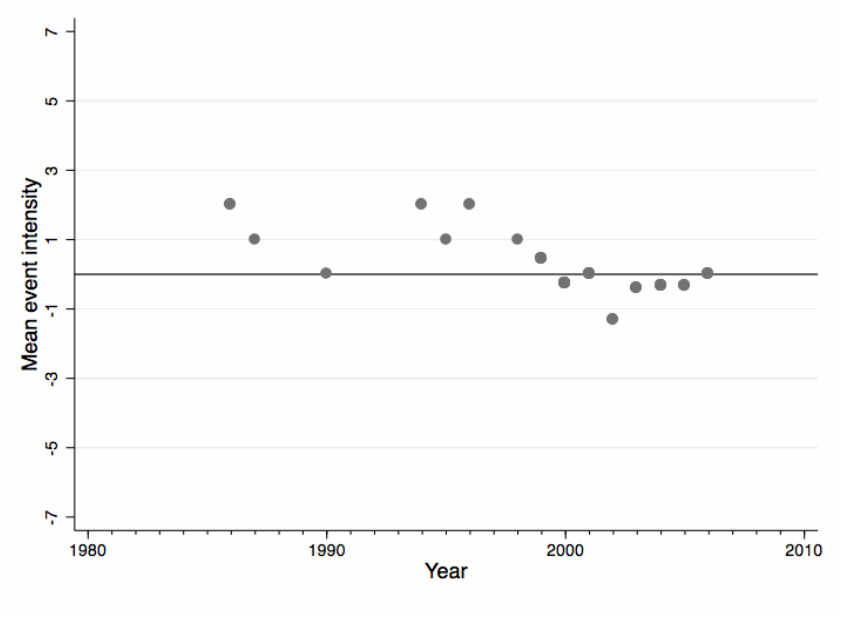

Most notably, this collaborative behavior includes bilateral investment in dam construction as well as efforts to establish a regional flood warning system. Thailand and Myanmar, for example, initiated a joint venture to develop five dams on the Salween River in 2004 (Wolf and Newton 2009), and China holds a controlling stake in the 228-m Tasang dam project in Myanmar (The Nation 2007). Chinese companies are also involved with the construction and finance of the Myitsone dam on the Myanmar stretch of the Salween River and might export Myanmar-generated hydroelectricity back to China even as China exports expertise and capital to Myanmar (Magee and Kelley 2009). It is important to note, however, that Myanmar's president, Thein Sein, suspended construction on that dam in September 2011, apparently in response to widespread public opposition (Fuller 2011). Although outside the time frame of our study, this event, among other recent events, including elections, may be both an indicator of domestic political change within Myanmar as well as an indicator of change in relations between Myanmar and China.

\section{Domestic hydro-political stability}

At different levels of government and in different spheres of society within China, the proposed dams on the Nu River in Yunnan have catalyzed both cooperation and conflict. Our domestic event data (Fig. 4) reveal the formation of an antidam coalition shortly after China's National Reform and Development Commission began developing plans for hydroelectric development of the Nu River basin in 1999 (Brown and Xu 2010). These domestic events reflect both conflictive behavior of protest as well as cooperation among members of coalitions. It is important to note that perceptions

Fig. 4. Average intensity of domestic interactions (within China) over water resources in the Salween River basin over time.

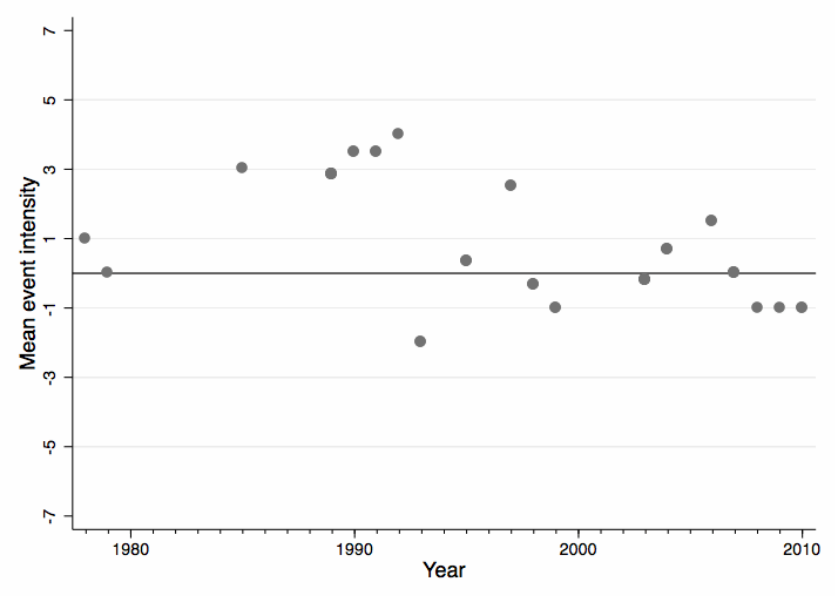


vary based on one's perspective: the Chinese government may view cooperation and subsequent dissent among residents opposed to dams as a cost, whereas otherwise marginalized citizens may view this as progress.

In general, we find evidence of cooperation at local levels of government. Against a backdrop of pro-development discourse that frames Yunnan as a key player in regional and national electrification, most local officials in the four counties of Nujiang Prefecture, for instance, see the hydroelectric cascade as a rational use of an undervalued resource and a vital tool for poverty alleviation. At the same time, we also find evidence of conflict across levels of government. For example, the National Reform and Development Commission initially approved the project in 2003, but later called for further study, effectively putting the project on hold in 2004. Premier Wen Jiabao officially suspended the project in 2004 (Mertha 2008), citing the developer's failure to conduct impact assessments in accordance with Chinese law. This contrast across levels of government is reflected in a trend of decreasing cooperation among domestic actors over time (Fig. 4). Indeed, despite the former Premier's call for a halt to the projects (which officially still holds), so-called preliminary work (qianqi gongzuo), including roads, diversion channels, resettlement villages, and related infrastructure is underway at several of the Nu River dam sites, suggesting that some of the projects may be gradually moving forward.

Our analysis supports McDonald's (2007) observation that basin residents tend to show less opposition to dam construction than do non-local actors. Although we document instances of local protest, our event data suggest that inspiration for protests comes from regional environmental activists rather than local residents. The literature identifies only a few domestic Chinese non-governmental organizations (NGOs) that oppose the proposed dams, including, for example, Green Watershed and Green Earth Volunteers. We document only two instances of local residents articulating opposition to the proposed dams: a petition and a gathering to express opposition. Foreign opposition is, however, more prolific. For example, nearly 80 foreign NGOs signed a letter opposing the dams in December 2003 and delivered it to the Chinese ambassador in Bangkok (Transboundary Freshwater Dispute Database 2012). Recent studies on water politics in China confirm the importance of non-local actors; the political system within China generally, and the $\mathrm{Nu}$ River basin specifically, is increasingly pluralized, and there are greater opportunities for non-state actors to insert themselves into the decision-making process (McDonald 2007, Mertha 2008).

\section{DISCUSSION}

\section{Vulnerability and geographic isolation}

One theme consistently reinforced in our data is that households, communities, and ecosystems that are marginalized geographically tend also to be marginalized economically, culturally, and politically. This phenomenon, which has been widely demonstrated in the political ecology literature (e.g., Blaikie and Brookfield 1987, Bryant and Bailey 1997), contributes to particularly acute, compound vulnerabilities at some of our study sites. From biophysical, socioeconomic, and geopolitical perspectives, there is a trend of increasing vulnerability from south to north in Nujiang Prefecture. For example, Maji, the northernmost study area, exhibits the lowest levels of wealth, the highest concentration of ethnic minorities, the lowest literacy rates, and the lowest levels of social cohesion. These factors all influence residents' abilities to cope with and adapt to the socioeconomic effects of the dam projects, including displacement and resettlement.

Potential biophysical vulnerabilities in Nujiang Prefecture also increase with geographical isolation from south to north and with an increase in reservoir size. While reservoir size, based on area and volume, is a basic indicator of biophysical vulnerability (Takeuchi 1997b), our results demonstrate ways in which spatial and geographic factors (e.g., proximity to conservation areas, valley configuration) also affect vulnerability to dams. For example, in Nujiang Prefecture, the magnitude of impact to conservation lands depends on a combination of reservoir size and geographic relationships between locations of hydropower projects and designated conservation lands, which are concentrated in the northern, more isolated portion of the study area. Our results highlight the value of characterizing potential vulnerability to dam development by more than dam size; biophysical vulnerability is a product of both dam characteristics and the location and features of the landscape in which the dam is located.

From a socioeconomic standpoint, geographic isolation appears to be related to wealth, literacy, access to information, and other measures of social vulnerability. The strongest vulnerabilities are related to resettlement, the adaptation of farming practices, and conversion to non-farm work opportunities. For example, when asked about potential negative effects of the hydropower projects, the most common themes cited were inundation of land, including both agricultural land and grazing land, and loss of homes. The inundation of land on the valley floor is particularly problematic in mountainous northwest Yunnan, where flat arable land is already exceedingly scarce. Paddy farmers may lack the expertise to plant upland crops or find alternative employment (Ponseti and López-Pujol 2006, Brown et al. 2008), and rebuilding food production capacity often takes years (Cernea 2000). These results confirm previous research that highlights how communities local to dam sites are more likely to incur the negative externalities of dam construction (Duflo and Pande 2007, Brown and Xu 2010, Foster-Moore 2011) and emphasize the importance of implementing resettlement and job programs that are appropriate for the cultures being displaced. 
Geographic isolation, and the associated trends in literacy and income, is also related to opportunities for participating in hydropower development planning. Recent revisions to national policies on compensation to displaced populations represent a major step forward from China's historically inadequate compensation structure. However, as is often the case, the trouble lies in the implementation of regulations. Just upstream from the Liuku Dam site, where preparatory work is underway, a total of 144 households from Xiaoshaba Village were relocated to New Xiaoshaba Village in 2007. Although public hearings were held in 2006, most villagers reported feeling intimidated and effectively shut out of the decisionmaking process. In addition, when resettlement took place, residents were required to purchase their new houses at an exorbitant price. More than a year after resettlement, no steps had been taken to allocate new farmland to the resettlers, and residents reported a lack of long-term support programs such as job training (Brown and $\mathrm{Xu}$ 2010). These results highlight how recognizing local social and cultural means of coping is crucial to a balanced transition during the resettlement process (Cernea 2000). To enhance the coping ability of local groups, introduction of local participation and integration of stakeholder interests must occur early in the planning process (van Kerkhoff and Lebel 2006, Wilmsen 2011). Yet as Mosse (2005) has pointed out, participation can be a barrier in itself because democratic principles and notions of individual rights are not cultural universals. Thus, it may be necessary to integrate multiple, flexible options for participation, rather than one overarching policy, because social and cultural contexts in each village may be quite different.

Geopolitically, there is a strong link between geographic isolation and the ability of people to engage in the political and planning process. We see evidence of this tendency in our data because isolated areas have fewer protests. The political events registered are a manifestation of peoples' concerns about potential economic and biophysical impacts, especially lost farmland, uncertain compensation, and general lack of clarity about the entire process. There are a number of reasons why rural, isolated people may not be protesting the dams. First, geographically-isolated people often do not know about the dam projects (Foster-Moore, unpublished data). As indicated in our household surveys, there is a great deal of variation in whether people knew about the dams: although 91\% of households in Liuku, the southernmost survey site, were aware of the planned dams, only $36 \%$ of households were aware of the dams in Maji, the northernmost survey site (Foster-Moore, unpublished data). Second, because the primary source of information for most residents is the local government, whose leaders generally support the projects, local people may not receive full information about the negative effects of the project. Third, local people may truly support the projects. Finally, local people may want to protest the projects but might feel political pressure to avoid protest. All of these factors likely drive the empirical observations that there are fewer protests and less knowledge about the dams among the more isolated local communities, which we argue reflects a higher level of vulnerability among the local population.

\section{Vulnerability and access to information}

In addition to geographic isolation, other factors may influence the ability of people and the environment to anticipate, cope with, and recover from changes associated with hydropower development. Chief among these are uncertainty and limited access to information, both of which contribute considerably to vulnerability. Our results indicate that insufficient information pathways and subsequent lack of detailed knowledge regarding dam building processes and projected consequences may limit the potential for residents of Nujiang Prefecture to anticipate and adapt to changes.

Uncertainty regarding magnitudes of potential biophysical effects is extensive with regard to the proposed Nu River dams. We note the substantial ranges of values predicted for biophysical vulnerabilities, based on uncertainties regarding dam locations and reservoir operations and on assumptions regarding annual and daily post-dam streamflows (Table 5). As the biophysical results of this study indicate, many effects of dam construction relate to reservoir extent, estimates of which contain significant levels of uncertainty. Currently, China's central government restricts certain hydrological and hydrodevelopment data because of perceived political sensitivity. Such control of information frequently results in substantial scientific uncertainties about ecosystem and socioeconomic impacts (e.g., number of displaced communities and residents), which can lead to confusion among those affected, complicating local and regional decision-making about hydropower development. Moreover, with regard to downstream areas, both benefits and costs of the projects are driven by variability in the hydrograph. However, without basic planning-level information regarding potential reservoir operations, analysis of vulnerability in downstream riparian areas is not possible. Thus, while projected effects within the reservoir reach are characterized by high uncertainty, effects to downstream areas are even more ambiguous.

Furthermore, the results of our simple analysis of the potential for reservoir-triggered seismicity highlight the need for further information and discussion of hydropower development in seismically-sensitive areas. Evidence of the sensitivity or insensitivity of an area to reservoir-induced seismicity may influence opinions regarding the benefits and risks of dams, yet this information is rarely disseminated during planning processes. Currently, little to no information is available regarding the likelihood of triggered seismic events in Nujiang Prefecture. Thus, our results highlight a need for the public participation process to integrate information regarding the subsurface geology, faults, and stresses to identify whether an area is seismically sensitive. 
Specific to the socioeconomic realm, access to information may influence the approval of the projects and participation in the planning process. The vast majority (94\%) of villagers who participated in our household surveys report that they support the construction of dams in general in China, and a similar majority (87\%) support the Nu River Projects in particular. Most participants cite electricity generation and economic growth as the most salient benefits that would likely come from dam construction. However, access to information about the projects is limited: at the time of household survey (2009), $41 \%$ of households were unaware that dam construction is planned for the Nu River valley (Foster-Moore, unpublished data). Furthermore, most villagers (59\%) lacked systematic information about specific plans for hydropower development (Foster-Moore, unpublished data). Efforts to increase access to information about the projects are needed as an important means of reducing vulnerability of affected populations.

\section{Vulnerability, conflict, and cooperation in international basins}

Institutions influence relationships and decision-making within river basins, and the lack of basin-wide institutions, either domestic or international, in the $\mathrm{Nu}$ and broader Salween River basin provides space for inequitable distribution of effects, unilateral decision-making, and the potential for geopolitical tensions arising from large-scale hydropower development within the territorial boundaries of the upstream riparian state (China). Even though we find evidence of tension and conflict over China's plans to build dams on the $\mathrm{Nu}$, parallel processes of cooperation at the international scale among the riparian nations are likely to prevent the escalation of conflict.

From the geopolitical perspective, the most obvious indicator of vulnerability to hydropower development is the lack of international institutional capacity. Previous research suggests that conflict over freshwater resources at the international level is more likely when physical or institutional change within the basin outpaces the capacity of the basin's governance structure to absorb change (Wolf et al. 2003a,b). Specifically, Wolf et al. $(2003 b)$ demonstrate that unilateral development actions in the absence of a freshwater treaty can lead to hydro-political conflict. China's proposed dams on the Nu River represent such a unilateral development action: China is not seeking, nor is it required to seek, permission to build dams domestically.

However, despite the lack of institutional capacity, the observed tone of interactions suggests that transboundary relations are relatively stable. Although conflictive events among the three riparian nations (China, Thailand, and Myanmar) have increased in frequency on the Nu River since the 1990s, coinciding with the advancement of hydropower development plans, the three governments have continued to cooperate over hydropower development and financing. Across basins where the balance of power is clear (e.g., China's economic powerhouse vs. Myanmar's weak economy, which is largely dependent on China), economic and investment-based collaboration may be more effective than political agreements.

Further, Zeitoun and Mirumachi (2008) point out that international events also often contain elements of both conflict and cooperation. Most conflict issues arise from foreign public interest groups, who oppose the socioeconomic and environmental effects of the dams, though these groups seem to have little impact on the nature of government-togovernment interactions. Common interests in exploiting the water resources of the $\mathrm{Nu}$ River for hydroelectricity appear to drive cooperation among the riparian governments, though recent actions (especially the opening of Myanmar) may indicate a changing political environment in the region.

\section{CONCLUSIONS}

The $\mathrm{Nu}$ River cascade is one of the largest and most controversial hydro-development projects in recent years. Given the multiple ways in which uniqueness (e.g., ecological, cultural) and marginality (e.g., geographical, socioeconomic) play a role, our research offers new and timely insight regarding vulnerabilities to hydropower. We have identified and characterized sources of biophysical, socioeconomic, and geopolitical vulnerability related to hydropower development in China's Nu River basin. In particular, geographic isolation appears to be a key source of vulnerability for people and the environment. Limitations on access to information also emerged as an important theme influencing social and environmental vulnerability.

Identifying the sources of vulnerability to hydropower development is an essential step toward increasing adaptive capacity and reducing the vulnerability of affected people and places. For example, our results highlight the importance of: ensuring that geographically isolated people are participating in the planning process and getting access to information; developing not only strong environmental mitigation and resettlement policies but also effective and transparent programs for implementation; and conducting more complete and publicly accessible mapping of geology, hydrology, and biodiversity, particularly in isolated and remote areas, to understand better the risks and how to manage them. Further work that explicitly investigates the geographic variability of human and environmental vulnerabilities constitutes an important research priority in river basin planning and management.

Beyond the Nu River case study, our analysis emphasizes the importance of identifying and addressing vulnerabilities related to hydropower development elsewhere in China and worldwide. It is clear that hydro-development decisionmaking entails a complex blend of scientific, technical, and 
political issues. Scientists can help inform decision-making by providing information on the range of evidence that should be considered (Brown et al. 2009) in the context of the biophysical, socioeconomic, and geopolitical domains, and through developing deeper understanding of relationships among those domains. Governments can establish more transparent development and decision-making processes by participating in transboundary treaties and organizations and by actively contributing to data dissemination and exchange. Such efforts will contribute to minimizing vulnerabilities and represent important steps toward integrated, multi-criteria river basin management.

Responses to this article can be read online at: http://www.ecologyandsociety.org/issues/responses. php/5465

\section{Acknowledgments:}

Funding for this work was provided by the U.S. National Science Foundation (awards \#0623087 and \#0826752). We gratefully acknowledge the contributions of Phil Brown to the development, implementation, and analysis of the household surveys.

\section{LITERATURE CITED}

Adger, W. N. 2006. Vulnerability. Global Environmental Change 16(3):268-281. http://dx.doi.org/10.1016/j.

gloenvcha.2006.02.006

ASTER. 2009. Advanced Spaceborne Thermal Emission Radiometer global digital elevation model validation summary support. METI/ERSDAC, NASA/LPDAAC, USGS/EROS.

Baecher, B. G., and R. L. Keeney. 1982. Statistical examination of reservoir-induced seismicity. Bulletin of the Seismological Society of America 72:553-569.

Blaikie, P. M., and H. C. Brookfield. 1987. Land degradation and society. Methuen, London, UK.

Brooks, N. 2003. Vulnerability, risk, and adaptation: a conceptual framework. Tyndall Centre for Climate Change Research, University of East Anglia, Norwich, UK.

Brown, P. H., D. Magee, and Y. Xu. 2008. Socioeconomic vulnerability in China's hydropower development. China Economic Review 19(4):614-627. http://dx.doi.org/10.1016/j. chieco.2008.06.002

Brown, P. H., D. Tullos, B. Tilt, D. Magee, and A. T. Wolf. 2009. Modeling the costs and benefits of dam construction from a multidisciplinary perspective. Journal of Environmental Management 90(S3):S303-S311. http://dx.doi.org/10.1016/j. jenvman.2008.07.025

Brown, P. H., and K. Xu. 2010. Hydropower development and resettlement policy on China's $\mathrm{Nu}$ River. Journal of Contemporary China 19(66):777- 797. http://dx.doi. org/10.1080/10670564.2010.485409

Bryant, R. L., and S. Bailey. 1997. Third World political ecology. Routledge, London, UK.

Cernea, M. M. 2000. Risks, safeguards and reconstruction: a model for population displacement and resettlement. Economic and Political Weekly 35(41):3659-3678.

Chen, L., and P. Talwani. 1998. Reservoir-induced seismicity in China. Pure and Applied Geophysics 153(1):133-149. http://dx.doi.org/10.1007/s000240050188

Chinese Statistical Bureau. 2000. China Statistical Yearbook. National Bureau of Statistics, Beijing, China.

De Stefano, L., J. Duncan, S. Dinar, K. Stahl, K. M. Strzepek, and A. T. Wolf. 2012. Climate change and the institutional resilience of international river basins. Journal of Peace Research 49(1):193-209. http://dx.doi.org/10.1177/0022343311427416

De Stefano, L., P. Edwards, L. de Silva, and A. T. Wolf. 2010. Tracking cooperation and conflict in international basins: historic and recent trends. Water Policy 12(6):871-884. http:// dx.doi.org/10.2166/wp.2010.137

Dore, J., and X. Yu. 2004. Yunnan hydropower expansion: update on China's energy industry reforms and the $\mathrm{Nu}$, Lancang and Jinsha hydropower dams. Working Paper. Chiang Mai University Unit for Social and Environmental Research, Chiang Mai, Thailand, and Green Watershed, Kunming, China. [online] URL: http://www.sea-user.org/ download_pubdoc.php?doc=2586.

Duflo, E., and R. Pande. 2007. Dams. Quarterly Journal of Economics 122(2):601-646. http://dx.doi.org/10.1162/qjec.122.2.601

Eakin, H., and A. L. Luers. 2006. Assessing the vulnerability of social-environmental systems. Annual Review of Environment and Resources 31:365-394. http://dx.doi. org/10.1146/annurev.energy.30.050504.144352

Fesler, K. J. 2007. An analysis of water resource conflict and cooperation in Oregon between 1990 and 2004. Thesis. Oregon State University, Corvallis, Oregon, USA. [online] URL: http://hdl.handle.net/1957/5700.

Field, J. 2003. Social capital. Routledge, London, UK.

Foster-Moore, E. 2011. A topography of dams in China: impacts to agriculture, labor, and migration. Thesis. Oregon 
State University, Corvallis, Oregon, USA. [online] URL: http://hdl.handle.net/1957/23457.

Fourniadis, I. G., J. G. Liu, and P. J. Mason. 2007. Landslide hazard assessment in the Three Gorges area, China, using ASTER imagery: Wushan-Badong. Geomorphology 84:(1-2) 126-144. http://dx.doi.org/10.1016/j.geomorph.2006.07.020

Friedl, G., and A. Wüest 2002. Disrupting biogeochemical cycles: consequences of damming. Aquatic Sciences 64 (1):55-65. http://dx.doi.org/10.1007/s00027-002-8054-0

Fuller, T. 2011. Myanmar backs down, suspending dam project. New York Times Oct. 1, 2011:4. Print.

Füssel, H.-M. 2007. Vulnerability: a generally applicable conceptual framework for climate change research. Global Environmental Change 17(2):155-167. http://dx.doi.org/10.1016/ j.gloenvcha.2006.05.002

Goldsmith, E., and N. Hildyard. 1986. The social and environmental effects of large dams. Volume II: case studies. Wadebridge Ecological Centre, Camelford, UK.

Goodman, D. S. G. 2004. The campaign to "Open up the West": national, provincial-level and local perspectives. China Quarterly 178:317-334. http://dx.doi.org/10.1017/ $\underline{\text { S0305741004000190 }}$

Gritti, E. S., B. Smith, and M. T. Sykes. 2006. Vulnerability of Mediterranean basin ecosystems to climate change and invasion by exotic plant species. Journal of Biogeography 33 (1):145-157. http://dx.doi.org/10.1111/j.1365-2699.2005.01377. $\underline{\mathrm{x}}$

Gunderson, L. H., and C. S. Holling, editors. 2002. Panarchy: understanding transformations in human and natural systems. Island Press, Washington, D.C., USA.

Gupta, H. K. 2002. A review of recent studies of triggered earthquakes by artificial water reservoirs with special emphasis on earthquakes in Koyna, India. Earth-Science Reviews 58(3-4):279-310. http://dx.doi.org/10.1016/S0012-8252 (02)00063-6

He, D. M., Y. Feng, and J. M. Hu. 2007. Zhongguo xinan guiji heliu shui ziyuan liyong yu shengtai baohu (Utilization of water resources and environmental conservation in the international rivers, southwest China). Science Press, Beijing, China.

He, Y., and J. Feng. 2004. Kexue fazhan guan yu Nujiang shuidian kaifa (Scientific development viewpoint and Nujiang hydropower development). Pages 7-12 in J. Feng and Y. He, editors. Nu Jiang, Lancang Jiang, Jinsha Jiang shuineng ziyuan kaifa yu huanjing baohu yanjiu. Zhongguo Xinan Minzu Yanjiu Xuehui, Kunming, China.
International Commission on Large Dams. 2003. World register of dams. Fourth edition. Paris, France.

International Union for the Conservation of Nature (IUCN). 2001. IUCN red list categories and criteria: version 3.1. IUCN Species Survival Commission, Gland, Switzerland. [online] URL: http://www.iucnredlist.org/technical-documents/categoriesand-criteria/2001-categories-criteria.

Ionescu, C., R. J. T. Klein, J. Hinkel, K. S. K. Kumar, and R. Klein. 2009. Towards a formal framework of vulnerability to climate change. Environmental Modeling and Assessment 14 (1):1-16. http://dx.doi.org/10.1007/s10666-008-9179-x

Janssen, M. A. 2007. An update on the scholarly networks on resilience, vulnerability, and adaptation within the human dimensions of global environmental change. Ecology and Society12(2): 9. [online] URL: http://www.ecologyandsociety. org/vol12/iss2/art9/.

Janssen, M. A., M. L. Schoon, W. Ke, and K. Börner. 2006. Scholarly networks on resilience, vulnerability and adaptation within the human dimensions of global environmental change. Global Environmental Change 16(3):240-252. http://dx.doi. org/10.1016/j.gloenvcha.2006.04.001

Jiemin, L., G. Jiang, J. Liu, Q. Zhou, and Z. Yao. 2003. Evaluation of methyltin and butyltin pollution in Beijing Guanting Reservoir and its downriver Yongding River. Bulletin of Environmental Contamination and Toxicology 70 (2):219-225. http://dx.doi.org/10.1007/s00128-002-0180-9

Junk, W. J., P. B. Bayley, and R. E. Sparks. 1989. The flood pulse concept in river-floodplain systems. Canadian Special Publication of Fisheries and Aquatic Sciences 106:110-127.

Kasperson, R. E., K. Dow, E. Archer, D. Caceras, T. E. Downing, T. Elmqvist, S. Eriksen, C. Folke, G. Han, K. Iyengar, C. Vogel, K. A. Wilson, and G. Ziervogel. 2005. Vulnerable peoples and places. Pages 146-163 in R. M. Hassan, R. J. Scholes, and N. Ash, editors. Ecosystems and human well-being: current state and trends, volume 1. Island Press, Washington, D.C., USA.

Kibler, K. M. 2011. Development and decommissioning of small dams: analysis of impact and context. Dissertation. Oregon State University, Corvallis, Oregon, USA. [online] URL: http://hdl.handle.net/1957/22821.

King, P., J. Bird, and L. Haas. 2007. The current status of environmental criteria for hydropower development in the Mekong region: a literature compilation. Consultant report to Asian Development Bank, Mekong River Commission Secretariat and World Wide Fund for Nature, Vientiane, Vietnam. 
Klose, C. D. 2012. Evidence for anthropogenic surface loading as trigger mechanism of the 2008 Wenchuan earthquake. Environmental Earth Sciences 66(5):1439-1447. http://dx. doi.org/10.1007/s12665-011-1355-7

Langhammer, P. F., M. I. Bakarr, L. A. Bennun, T. M. Brooks, R. P. Clay, W. Darwall, N. De Silva, G. J. Edgar, G. Eken, L. D. C. Fishpool, G. A. B. da Fonseca, M. N. Foster, D. H. Knox, P. Matiku, E. A. Radford, A. S. L. Rodrigues, P. Salaman, W. Sechrest, and A. W. Tordoff. 2007. Identification and gap analysis of key biodiversity areas: targets for comprehensive protected area systems. IUCN, Gland, Switzerland. http://dx. doi.org/10.2305/IUCN.CH.2006.PAG.15.en

Leichenko, R. M., and K. L. O'Brien. 2002. The dynamics of rural vulnerability to global change: the case of southern Africa. Mitigation and Adaptation Strategies for Global Change 7(1):1-18. http://dx.doi.org/10.1023/A:1015860421954

Liverman, D. M. 1990. Vulnerability to global environmental change. Pages 27-44 in R. E. Kasperson, K. Dow, D. Golding, and J. X. Kasperson, editors. Understanding global environmental change: the contributions of risk analysis and management. Clark University, Worcester, Massachusetts, USA.

Loague, K. 1994. Regional-scale groundwater vulnerability estimates: impact of reducing data uncertainties for assessments in Hawaii. Ground Water 32(4):605-616. http:// dx.doi.org/10.1111/j.1745-6584.1994.tb00896.x

Luo, H., G. Bao, and Z. Li. 2005. Analysis on the social and economic development and the factors about the exploitation of hydroelectric resources. Pages 4-12 in J. Feng and Y. He, editors. Nu Jiang, Lancangjiang, and Jinshajiang: researches on the exploitation of hydropower resources and the protection of environment. Social Sciences Documents Publishing Company, Beijing, China.

Magee, D. 2006. Powershed politics: Yunnan hydropower under Great Western Development. China Quarterly 185:23-41. http://dx.doi.org/10.1017/S0305741006000038

Magee, D. 2012. The dragon upstream: China's role in Lancang-Mekong development. Pages 171-194 in J. Öjendal, S. Hansson, and S. Hellberg, editors. Politics and development in a transboundary watershed: the case of the Lower Mekong basin. Springer, Dordrecht, The Netherlands. http://dx.doi. org/10.1007/978-94-007-0476-3_9

Magee, D., and S. Kelley. 2009. Damming the Salween River. Pages 115-140 in F. Molle, T. Foran, and M. Käkönen, editors. Contested waterscapes in the Mekong region hydropower, livelihoods and governance. Earthscan, London, UK.

Magee, D., and K. McDonald. 2006. Beyond Three Gorges: $\mathrm{Nu}$ River hydropower and energy decision politics in China. Asian Geographer 25(1-2):39-60.
McCarthy, J. M., O. F. Canziani, F.Osvaldo, N. A. Leary, D. J. Dokken, and K. S. White, editors. 2001. Climate change 2001: impacts, adaptation, and vulnerability. Report of Working Group II to the Third Assessment Report of the Intergovernmental Panel on Climate Change. Cambridge University Press, Cambridge, UK.

McDonald, K. N. 2007. Damming China's grand canyon: pluralization without democratization in the Nu River valley. Environmental science, policy, and management. Dissertation. University of California, Berkeley, California, USA.

McLaughlin, P., and T. Dietz. 2008. Structure, agency and environment: toward an integrated perspective on vulnerability. Global Environmental Change 18(1):99-111. http://dx.doi.org/10.1016/j.gloenvcha.2007.05.003

McNally, A., D. Magee, and A. T. Wolf. 2009. Hydropower and sustainability: resilience and vulnerability in China's powersheds. Journal of Environmental Management 90(S3): S286-S293. http://dx.doi.org/10.1016/j.jenvman.2008.07.029

Mertha, A. C. 2008. China's water warriors: citizen action and policy change. Cornell University Press, Ithaca, New York, USA.

Metzger, M. J., M. D. A. Rounsevell, L. Acosta-Michlik, R. Leemans, and D. Schröter. 2005. The vulnerability of ecosystem services to land use change. Agriculture, Ecosystems and Environment 114(1):69-85. http://dx.doi. org/10.1016/j.agee.2005.11.025

Miller, F., H. Osbahr, E. Boyd, F. Thomalla, S. Bharwani, G. Ziervogel, B. Walker, J. Birkmann, S. Van der Leeuw, J. Rockström, J. Hinkel, T. Downing, C. Folke, and D. Nelson. 2010. Resilience and vulnerability: complementary or conflicting concepts? Ecology and Society 15(3): 11. [online] URL: http://www.ecologyandsociety.org/vol15/iss3/art11/.

Mosse, D. 2005. Cultivating development: an ethnography of aid policy and practice. Pluto Press, London, UK.

Mustafa, D., S. Ahmed, E. Saroch, and H. Bell. 2011. Pinning down vulnerability: from narratives to numbers. Disasters 35 (1):62-86. http://dx.doi.org/10.1111/j.1467-7717.2010.01193. $\underline{\mathrm{X}}$

The Nation. 2007. Chinese make move. The Nation Nov. 21, 2007, Bangkok, Thailand. Print.

Naughton, B. J. 2004. The Western Development Program. Pages 253-296 in B. J. Naughton and D. L. Young, editors. Holding China together: diversity and national integration in the post-Deng era. Cambridge University Press, New York, New York, USA. http://dx.doi.org/10.1017/CBO9780511617157.009 
Nilsson, C., C. A. Reidy, M. Dynesius, and C. Revenga. 2005. Fragmentation and flow regulation of the World's large river systems. Science 308(5720):405-408. http://dx.doi.org/10.1126/ science. 1107887

Padovani, F. 2004. Les effets sociopolitiques des migrations forcées en Chine liées aux grands travaux hydrauliques: l'exemple du barrage des Trois-Gorges. (Socio-political effects of force migrations in China related to large hydraulic projects: the example of the Three Gorges). Les Etudes du CERI 103. CERI, Paris, France. [online] URL: http://www. sciencespo.fr/ceri/sites/sciencespo.fr.ceri/files/etude103.pdf.

Poff, N. L., J. D. Allan, M. B. Bain, J. R. Karr, K. L. Prestegaard, B. D. Richter, R. E. Sparks, and J. C. Stromberg. 1997. The natural flow regime: a paradigm for river conservation and restoration. Bioscience 47(11):769-784. http://dx.doi.org/10.2307/1313099

Ponseti, M., and J. López-Pujol. 2006. The Three Gorges Dam project in China: history and consequences. Revista Història Moderna i Contemporània (4):151-188. [online] URL: http:// www.raco.cat/index.php/HMIC/article/viewFile/57768/67739.

Postel, S., and B. D. Richter. 2003. Rivers for life: managing water for people and nature. Island Press, Washington, D.C., USA.

Schröter, D., W. Cramer, R. Leemans, I. C. Prentice, M. B. Araújo, N. W. Arnell, A. Bondeau, H. Bugmann, T. R. Carter, C. A. Gracia, A. C. de la Vega-Leinert, M. Erhard, F. Ewert, M. Glendining, J. I. House, S. Kankaanpää, R. J. T. Klein, S. Lavorel, M. Lindner, M. J. Metzger, J. Meyer, T. D. Mitchell, I. Reginster, M. Rounsevell, S. Sabaté, S. Sitch, B. Smith, J. Smith, P. Smith, M. T. Sykes, K. Thonicke, W. Thuiller, G. Tuck, S. Zaehle, and B. Zierl. 2005. Ecosystem service supply and vulnerability to global change in Europe. Science 310 (5752):1333-1337. http://dx.doi.org/10.1126/science.1115233

Scudder, T. 2005. The future of large dams: dealing with social, environmental, institutional and political costs. Earthscan, Sterling, Virginia, USA.

Stohlgren, T. L., G. W. Chong, L. D. Schell, K. A. Rimar, Y. Otsuki, M. Lee, M. A. Kalkhan, and C. A. Villa. 2002. Assessing vulnerability to invasion by non-native plant species at multiple spatial scales. Environmental Management 29(4):566-577. http://dx.doi.org/10.1007/s00267-001-0006-2

Takeuchi, K. 1997a. Least marginal environmental impact rule for reservoir development. Hydrological Sciences Journal 42(4):583-597. http://dx.doi.org/10.1080/02626669709492055

Takeuchi, K. 1997b. On the scale diseconomy of large reservoirs in land occupation. Pages 519-527 in D. Rosbjerg, N.-E. Boutayeb, A. Gustard, Z. W. Kundzewicz, and P. F. Rasmussen, editors. Sustainability of water resources under increasing uncertainty. International Association of Hydrological Sciences, Wallingford, UK.
Talwani, P. 1997. On the nature of reservoir-induced seismicity. Pure and Applied Geophysics 150(3-4):473-492. http://dx.doi.org/10.1007/s000240050089

Timmerman, P. 1981. Vulnerability, resilience and the collapse of society: a review of models and possible climatic applications. Institute for Environmental Studies, University of Toronto, Toronto, Canada.

Transboundary Freshwater Dispute Database. 2012. Transboundary Freshwater Dispute Database. Oregon State University, Corvallis, Oregon, USA. [online] URL: http:// www.transboundarywaters.orst.edu/database.

Turner, B. L., II, R. E. Kasperson, P. A. Matson, J. J. McCarthy, R. W. Corell, L. Christensen, N. Eckley, J. X. Kasperson, A. Luers, M. L. Martello, C. Polsky, A. Pulsipher, and A. Schiller. 2003. A framework for vulnerability analysis in sustainability science. Proceedings of the National Academy of Sciences 100 (14):8074-8079. http://dx.doi.org/10.1073/pnas.1231335100

Twigg, J. 2007. Characteristics of a disaster-resilient community: a guidance note. Version 1. Department for International Development (DFID) Disaster Risk Reduction, London, UK. [online] URL: https://practicalaction.org/docs/ ia1/community-characteristics-en-lowres.pdf.

UNESCO World Heritage Convention. 2003. Three parallel rivers of Yunnan protected areas. UNESCO, Paris, France. [online] URL: http://whc.unesco.org/en/list/1083.

van Kerkhoff, L., and L. Lebel. 2006. Linking knowledge and action for sustainable development. Annual Review of Environment and Resources 31:445-447. http://dx.doi. org/10.1146/annurev.energy.31.102405.170850

Villa, F., and H. McLeod. 2002. Environmental vulnerability indicators for environmental planning and decision-making: guidelines and applications. Environmental Management 29 (3):335-348. http://dx.doi.org/10.1007/s00267-001-0030-2

Vörösmarty, C. J., M. Meybeck, B. Fekete, K. Sharma, P. Green, and J. P. M. Syvitski. 2003. Anthropogenic sediment retention: major global impact from registered river impoundments. Global and Planetary Change 39 (1-2):169-190. http://dx.doi.org/10.1016/S0921-8181(03)00023-7

Walker, W. W., Jr. 1983. Significance of eutrophication in water supply reservoirs. Journal of the American Water Works Association 75(1):38-42.

Wang, J. 2002. Three Gorges project: the largest water conservancy project in the world. Public Administration and Development 22(5):369-375. http://dx.doi.org/10.1002/pad.241

Wickham, J. D., R. V. O’Neill, and K. B. Jones. 2000. A geography of ecosystem vulnerability. Landscape Ecology 15 (6):495-504. http://dx.doi.org/10.1023/A:1008176120891 
Wilmsen, B. 2011. Progress, problems, and prospects of daminduced displacement and resettlement in China. China Information 25(2):139-164. http://dx.doi.org/10.1177/0920203X11407544

Wolf, A. T. 1999. The Transboundary Freshwater Dispute Database project. Water International 24(2):160-163. http:// dx.doi.org/10.1080/02508069908692153

Wolf, A. T., and J. T. Newton. 2009. Case studies of transboundary dispute resolution: Salween River. Pages 236-239 in J. Delli Priscoli and A. T. Wolf, editors. Managing and transforming water conflicts. Cambridge University Press, Cambridge, UK.

Wolf, A. T., K. Stahl, and M. F. Macomber. 2003a. Conflict and cooperation within international river basins: the importance of institutional capacity. Water Resources Update 125:31-40. [online] URL: http://www.transboundarywaters. orst.edu/publications/abst docs/Wolf_2003.pdf.

Wolf, A. T., S. B. Yoffe, and M. Giordano. $2003 b$. International waters: identifying basins at risk. Water Policy 5(1):29-60.

World Commission on Dams. 2000. Dams and development: a new framework for decision-making. Earthscan, London, UK.

Xu, J. C., and A. Wilkes. 2004. Biodiversity impact analysis in northwest Yunnan, southwest China. Biodiversity and Conservation 13(5):959-983. http://dx.doi.org/10.1023/B: BIOC.0000014464.80847.02

Yang, Y., K. Tian, J. Hao, S. Pei, and Y. Yang. 2004. Biodiversity and biodiversity conservation in Yunnan, China. Biodiversity and Conservation 13(4):813-826. http://dx.doi. org/10.1023/B:BIOC.0000011728.46362.3c

Yoffe, S. 2001. Basins at risk: conflict and cooperation over international freshwater resources. Dissertation. Oregon State University, Corvallis, Oregon, USA. [online] URL: http://hdl. handle.net/1957/9693.

Yoffe, S., A. T. Wolf, and M. Giordano. 2003. Conflict and cooperation over international freshwater resources: indicators of basins at risk. Journal of the American Water Resources Association 39(5):1109-1126. http://dx.doi. org/10.1111/j.1752-1688.2003.tb03696.x

Zahran, S., S. D. Brody, W. G. Peacock, A. Vedlitz, and H. Grover. 2008. Social vulnerability and the natural and built environment: a model of flood casualties in Texas. Disasters 32(4):537-560. http://dx.doi.org/10.1111/j.1467-7717.2008.01054. $\underline{\mathrm{X}}$

Zeitoun, M., and N. Mirumachi. 2008. Transboundary water interaction I: reconsidering conflict and cooperation.
International Environmental Agreements: Politics, Law and Economics 8(4):297-316. http://dx.doi.org/10.1007/ $\underline{\text { s10784-008-9083-5 }}$

Zhou, D., and J. Zhang, editors. 2003. Zhongguo shuili fadian nianjian 2001-2002 (Almanac of China's water power 20012002). Volume 7. Zhongguo dianli chubanshe, Beijing, China. 